\title{
Terminal Electron Acceptors for Controlling Methane Emissions from Submerged Rice Soils
}

\author{
K. L. Sahrawat* \\ International Crops Research Institute for the Semi-arid Tropics \\ (ICRISAT), Patancheru, Andhra Pradesh, India
}

\begin{abstract}
Wetland rice fields are source of atmospheric methane. Methane is formed following reduction of carbon dioxide by hydrogen and through decarboxylation of acetate in anaerobic soils under reduced conditions. Methane production requires flow of carbon and electrons to microbial population of methanogens under reduced conditions in the strict absence of free oxygen. Application of or in-situ availability of terminal electron acceptors (oxidants) such as ferric iron or sulfate allows iron or sulfate reducers to successfully
\end{abstract}

*Correspondence: Dr. K. L. Sahrawat, International Crops Research Institute for the Semi-arid Tropics (ICRISAT), Patancheru 502324, Andhra Pradesh, India; Fax: +91 40 23241239/23296182; E-mail: klsahrawat@yahoo.com.

1401

DOI: $10.1081 /$ CSS-120037554

Copyright $\odot 2004$ by Marcel Dekker, Inc.
0010-3624 (Print); 1532-2416 (Online) www.dekker.com 
compete for substrates, hydrogen or acetate, with methanogens. This stops methane production. Electron acceptors also oxidize methane and reduce its emission. Since iron redox system plays a dominant role in tropical rice soils, which are rich in iron, the role of iron oxides and hydroxides as electron acceptor for controlling methane emission from wetland rice fields deserves more attention. For mitigating methane emission from wetland rice fields, ferric iron as a terminal electron-accepting agent, can either be added to the soil or regenerated in the soil by manipulating redox potential through soil and water management. Examples are given from recent literature illustrating the role of electron acceptors (ferric iron, sulfate, etc.) in reducing methane emission from submerged rice soils. The need for future research is also examined.

Key Words: Anaerobiosis; Carbon flow; Electron acceptors; Ferric-ferrous redox; Methanogens; Methane oxidation and emission; Soil and water management; Sulfate.

\section{INTRODUCTION}

The involvement of greenhouse gases in global warming has focused attention on the ways to mitigate their emission from lowland rice fields, which are source of methane emission to the atmosphere. Methane $\left(\mathrm{CH}_{4}\right)$ ranks second only to carbon dioxide $\left(\mathrm{CO}_{2}\right)$ among the greenhouse gases: $\mathrm{CO}_{2}, \mathrm{CH}_{4}$, chlorofluorocarbons (CFCs), and nitrous oxide $\left(\mathrm{N}_{2} \mathrm{O}\right)$, for its contribution to global warming. ${ }^{[1]}$ Although the concentration of methane is far lower than that of carbon dioxide in the atmosphere, it has high thermal adsorption and hence its contribution to global warming is more than its concentration would suggest.

Recent reviews ${ }^{[2,3]}$ comprehensively cover the aspects of methane production and its fluxes from lowland rice fields, and crop and water management strategies for mitigating methane emission from wetland rice paddies.

Methane is produced as the terminal step of the anaerobic decomposition of organic matter in wetland soils. Methanogenic bacteria exclusively produce methane in the strict absence of free oxygen and at redox potentials of less than $-150 \mathrm{mV} .^{[4]}$ The methanogens are best at work at a $\mathrm{pH}$ of $6-8$ and a temperature of $30-40^{\circ} \mathrm{C}^{[5]}$ In wetland rice soils, methane is produced (i) by transmethylation or decarboxylation of acetic acid, and (ii) by the reduction of carbon dioxide. ${ }^{[6]}$ Methane 
production by these two pathways can be represented by the following reactions:

$$
\begin{aligned}
& \mathrm{CO}_{2}+\mathrm{H}_{2}=\mathrm{CH}_{4}+2 \mathrm{H}_{2} \mathrm{O} \\
& \mathrm{CH}_{3} \mathrm{COOH}=\mathrm{CH}_{4}+\mathrm{CO}_{2}
\end{aligned}
$$

The formation of methane is preceded by the production of volatile acids. Hydrogen evolution follows the disappearance of oxygen following flooding of the soil into water. In this sequence, carbon dioxide evolution is followed by methane formation and emission. ${ }^{[7]}$

The production of $\mathrm{CH}_{4}$ is controlled by the flow of carbon (C) and electrons to the microbial community of methanogens during anaerobic organic matter degradation process. Also, thermodynamic constraints of the in-situ reactions involved and changes in the composition of microbial community affect methane production. ${ }^{[8]}$ An understanding of the in-situ processes involved on a microscopic level provide leads for developing strategies for controlling methane production and emission. Conrad $^{[8]}$ has reviewed the existing knowledge of microbiological data, microscopic processes, and other factors relevant for the control of methane production in wetland rice fields.

The main electron-acceptors in submerged soils include dissolved oxygen $\left(\mathrm{O}_{2}\right), \mathrm{NO}_{3}^{-}, \mathrm{Fe}(\mathrm{III}), \mathrm{SO}_{4}^{2-}$, and $\mathrm{CO}_{2}$. The final products of reduction in submerged soils are $\mathrm{Fe}$ (II) from $\mathrm{Fe}$ (III), $\mathrm{H}_{2} \mathrm{~S}$ from $\mathrm{SO}_{4}^{2-}$ and $\mathrm{CH}_{4}$ from $\mathrm{CO}_{2}$. In principle, mitigation in methane production can be achieved by adding electron acceptors and oxidants. However, electron-acceptors such as ferric iron or sulfate are preferred for this role because they allow iron reducers or sulfate reducers to successfully compete for substrates, hydrogen and acetate, with methanogens. This stops methane production and emission.

The use of electron acceptors for mitigating methane emission from wetland rice fields seems attractive, especially in tropical rice soils, which are relatively rich in iron and iron redox dominates all other redox species combined in wetland soils. ${ }^{[9,10]}$ But this area of research has not received the attention it deserves. This article critically reviews the prospects of mitigating methane emission from wetland rice paddies by employing electron acceptors (oxidants), added or regenerated in the soil in-situ through soil and water management. The potential avenues of future research on the potential use of terminal electron accepting agents in reducing methane emissions are also examined. Since iron redox plays a dominant role in tropical wetland rice soils, ${ }^{[9,10]}$ its role as an electronaccepting agent for controlling methane emission, evidently receives greater attention. 


\section{TERMINAL ELECTRON ACCEPTORS FOR CONTROLLING METHANE EMISSION FROM SUBMERGED RICE SOILS}

Anaerobic decomposition of organic matter has been described as a two-phase step, premethanogenesis and methanogenesis. ${ }^{[11,12]}$ The reduction process in submerged soils follows the sequence: oxygen, nitrate, manganese $(\mathrm{Mn})$, iron $(\mathrm{Fe})$, sulfate, and carbon dioxide.

Molecular oxygen $\left(\mathrm{O}_{2}\right)$ is undetectable when redox potential $(\mathrm{Eh})$ is in the range of 380 to $320 \mathrm{mV}$; nitrate and $\mathrm{Mn}$ (IV) are unstable in the Eh range of 280 to $220 \mathrm{mV}$; Fe (III) is undetectable in the Eh range of 180 to $150 \mathrm{mV}$; sulfate is undetectable in the Eh range of -120 to $-180 \mathrm{mV}$ and carbon dioxide disappears in the Eh range of -200 to $-280 \mathrm{mV} .^{[9,10]}$

Carbon dioxide is reduced to methane at a very low Eh. If any of the oxidized components of $\mathrm{Fe}$ [Fe (III)], Mn [Mn (IV)], and N (nitrate) are present in the soil, the Eh is poised at a higher redox potential, and methane production is temporarily stopped until the oxidized species are reduced. As a corollary, the application of electron acceptors such as ferric $\mathrm{Fe}$ and sulfate can be used for retarding methane production and emission from submerged soils. This strategy is both sound and practical for reducing methane emission from rice paddies.

Because sulfate reduction occurs before methane formation in the sequence of reduction in submerged soils, ${ }^{[9,10]}$ the presence of sulfate potentially can inhibit methane formation in anaerobic soil systems. Evidently, sulfate reducers compete with methanogens for substrates, acetate, and $\mathrm{H}_{2}$, resulting in inhibition of methane formation. ${ }^{[13]}$ Based on the results from studies of organic matter-rich marine sediments, it was suggested that sulfate reduction and methane production are mutually exclusive and hence presence of sulfate halts, at least temporarily, the production of methane. ${ }^{[14]}$

Application of salts to wetland rice soils can affect methane production and emission. For example, addition of sodium chloride at relatively high concentration $(0.18 \mathrm{M})$ retards methane production. ${ }^{[15]}$ Addition of seawater also retards methane formation at relatively low rates of salt concentrations because of sulfate content in the seawater. ${ }^{[16]}$ The presence of sulfate provides the opportunity for sulfate reducers to compete with methanogens for hydrogen. Methane emission from wetland rice fields on saline, low-sulfate soils were lower than methane emission from otherwise comparable nonsaline rice fields. ${ }^{[17]}$ It was suggested that sodium chloride in saline lowland rice field reduced methane emission. The results were confirmed by adding sodium chloride to soil in the field, and the addition of sodium chloride indeed greatly 
reduced methane emission. Whether reduced methane emission was due to the inhibition of methane formation or due to methane oxidation however, could not be fully established.

The finding that sulfate reducers inhibit methane production in lowland soils by out-competing methanogens for substrates, has been tested for evaluating the effect of sulfate containing chemicals on methane production and emission. The addition of fertilizers, chemicals, or amendments (such as gypsum) containing sulfate indeed have been found to retard methane emission from rice paddies. ${ }^{[18-22]}$

Addition of single superphosphate, which also contains sulfur, as phosphorus $(\mathrm{P})$ source to flooded rice soils, not only supplied $\mathrm{P}$ to wetland rice, but also inhibited methane production. On the other hand, application of $\mathrm{P}$ as $\mathrm{K}_{2} \mathrm{HPO}_{4}$ was found to stimulate methane production in a P-deficient soil. Also, application of rock phosphates that contained sulfur retarded methane production, while rock phosphate sources that did not contain sulfur stimulated methane production. It was concluded that the application of single superphosphate to wetland rice could be used as methane mitigation strategy in P-deficient soils where addition of $\mathrm{P}$ is necessary for sustaining increased rice production and productivity. ${ }^{[21]}$

Lindau et al. ${ }^{[20]}$ evaluated the efficacy of application of calcium sulfate for mitigating methane evolution in irrigated rice field. Calcium sulfate was applied at 0,1000 , and $2000 \mathrm{~kg} \mathrm{ha}^{-1}$ to rice plots treated with urea $\left(128 \mathrm{~kg} \mathrm{Nha}^{-1}\right)$. It was found that calcium sulfate application reduced methane evolution 29 and $46 \%$ compared to control (no calcium sulfate applied) at the low $\left(1000 \mathrm{~kg} \mathrm{ha}^{-1}\right)$ and high rate $\left(2000 \mathrm{~kg} \mathrm{ha}^{-1}\right)$, respectively, over the 70 days sampling.

It is postulated that bacteria that utilize $\mathrm{H}_{2}$ by reducing sulfate or ferric iron are able to deplete $\mathrm{H}_{2}$ to concentration levels that methane production is not feasible. ${ }^{[8]}$ Microbial processes determining the different phases of methane production following flooding of soil are summarized in Table 1.

The penetration of oxygen during drainage of rice paddies allows oxidation of reduced sulfur to sulfate and ferrous Fe to ferric Fe. The production of sulfate and $\mathrm{Fe}$ (III) allows the utilization of $\mathrm{H}_{2}$ and acetate, the two most important substrates for methane production, by sulfatereducing and iron-reducing bacteria more efficiently than the methanogens. The concentrations of $\mathrm{H}_{2}$ and acetate are depleted to so low levels that methane production is not feasible. ${ }^{[23-25]}$ Indeed, the hydrogen concentration in aquatic sediments has been proposed as an indicator of the predominant terminal electron-accepting reactions. ${ }^{[26]}$ This finding should be equally applicable to submerged soils. 
Table 1. Microbial processes determining the various phases of methane production in wetlands following flooding of the soil. ${ }^{[8]}$

\begin{tabular}{llr}
\hline Phase & \multicolumn{1}{c}{ Microbial processes } & $\begin{array}{c}\text { Duration of } \\
\text { the phase }(\mathrm{d})\end{array}$ \\
\hline 0 & General lag phase & $<1$ \\
1 & Fermentation produces $\mathrm{H}_{2}$ and acetate & $<10$ \\
Iron reducers and sulfate reducers are still inactive & \\
Methane production is limited by the & $<30$ \\
methanogens themselves & $<30$ \\
Iron reducers and sulfate reducers become active & \\
They deplete $\mathrm{H}_{2}$ & \\
Methane production is suppressed by the & \\
deficiency of $\mathrm{H}_{2}$ & \\
Iron(III) and sulfate are depleted & \\
Iron reducers and sulfate reducers become \\
inactive \\
Concentration of $\mathrm{H}_{2}$ increases again, acetate \\
conc. still high \\
Production of $\mathrm{CH}_{4}$ is thus possible at a relatively \\
high rate \\
Fermentation is getting limited by hydrolysis of \\
biopolymers
\end{tabular}

Wetland rice soils with high amounts of easily decomposable organic matter and substrates such as acetate and $\mathrm{H}_{2}$, and low amounts of electron acceptors such as ferric iron and sulfate, under reduced conditions, are likely to produce higher amounts of methane. ${ }^{[18]}$ Moreover, the extent and duration for which methane production is suppressed is mainly controlled by the ratio of easily oxidizable organic matter to easily reducible iron ${ }^{[8]}$ Also, recent research established organic matter and reducible iron (extracted by ammonium oxalate or EDTA) control of $\mathrm{N}$ mineralization in submerged rice soils. ${ }^{[27]}$ The reviews of recent research emphasized the importance of iron that participates in redox reactions, estimated by the amount of reducible iron, in controlling the oxidation of organic matter and $\mathrm{N}$ mineralization in wetland soils and sediments. ${ }^{[28,29]}$ 
Since iron redox plays a dominant role as electron acceptor in wetland rice soils, ${ }^{[9]}$ its role as an oxidant in wetland rice soils is equally important. Recent research showed that iron that participates in redox reactions accounts for over $50 \%$ of the organic $\mathrm{C}$ that is oxidized to carbon dioxide in the season. ${ }^{[30]}$ This conclusion is supported by the results of a study made in Italy, which showed that relatively high concentration of ferric iron, to a minor extent of sulfate, in rice fields resulted in acetate conversion to carbon dioxide rather than to methane. A decrease in acetate concentration resulted in decreased methane production rate. ${ }^{[31]}$ It was concluded that the generation of ferric iron as an electron acceptor might result in dramatic reduction in methane production.

In earlier studies made in Japan, it was hypothesized that the ratios of the final $\mathrm{C}$ products of organic matter decomposition in anaerobic soil- $-\mathrm{CO}_{2}: \mathrm{CH}_{4}$ is regulated by the ratio of oxidizing capacity to reducing capacity. The amounts of reducible oxygen, nitrate, Mn (IV), and Fe (III) (electron acceptors) correspond to the oxidizing (electron accepting) capacity, because these compounds act as the oxidants during the facultatively anaerobic step. Ammonium plus ammonia formation was taken as the index of reducing (electron donating) capacity, because ammonium is formed during anaerobic incubation from the easily decomposable organic matter. According to this hypothesis, higher the oxidizing capacity relative to reducing capacity of the soil, the higher the $\mathrm{CO}_{2}: \mathrm{CH}_{4}$ ratio. ${ }^{[32]}$

Asami and Takai ${ }^{[33]}$ found that the addition of amorphous iron oxide (electron acceptor) in anaerobically incubated soil depressed the accumulation of volatile fatty acids and methane. It was postulated that sesquioxide acted as a buffer to reduction of carbon dioxide in the methanogenic process. These results lend support to the hypothesis forwarded by Takai ${ }^{[32]}$ on the role of soil's oxidizing capacity in controlling methane production.

Koyama and Kimura ${ }^{[34]}$ studied the effects of application of ammonium sulfate, seawater (rich in sodium chloride and sulfate), iron oxide $\left(\mathrm{Fe}_{2} \mathrm{O}_{3}\right)$ and ferric hydroxide $\left[\mathrm{Fe}(\mathrm{OH})_{3}\right]$ containing less than $2 \%$ $\mathrm{Fe}$ and manganese dioxide $\left(\mathrm{MnO}_{2}\right)$, an oxidant, on methane production in paddy soils. It was found that application of ammonium sulfate $(1.14 \mathrm{~g}$ sulfate $\mathrm{kg}^{-1}$ soil) and seawater (containing sodium chloride and sulfate) inhibited methane production. The application of ferric oxide or ferric hydroxide, applied at $2.0 \mathrm{~g}$ of $\mathrm{Fe}$ (III) $\mathrm{kg}^{-1}$ soil, did not suppress methane production, probably due to low content of amorphous ferric oxide iron. But more importantly, the application of manganese dioxide, at a rate of O. $57 \mathrm{Mn}$ (IV) $\mathrm{kg}^{-1}$ soil, inhibited methane production. 
Manganese dioxide is an oxidant and retards soil reduction. It was observed that soils naturally high in manganese dioxide underwent slow reduction on flooding. Subsequently, it was found that the addition of manganese dioxide $(0.4 \%$ by weight of the soil) to flooded rice soils retarded soil reduction and improved the growth and yield of rice on two strongly acid soils in a greenhouse pot study. ${ }^{[35]}$

It is established that amorphous iron is easily reduced in submerged soils. The intensity of $\mathrm{Fe}(\mathrm{II})$ production in submerged soils increases with a decrease in crystallinity of the pedogenic Fe(III) oxides and hydroxides and with increase in the easily mineralizable organic matter. ${ }^{[3-39]}$ Moreover, soil organic materials have inhibitory effect on the crystallization of amorphous ferric hydroxides and help maintain iron in the amorphous and relatively reducible form. ${ }^{[40]}$ In these redox reactions, ferric iron serves as electron acceptor and organic matter $\left(\mathrm{CH}_{2} \mathrm{O}\right)$ as the electron donor:

$$
\mathrm{Fe}_{2} \mathrm{O}_{3}+1 / 2 \mathrm{CH}_{2} \mathrm{O}+4 \mathrm{H}^{+}=2 \mathrm{Fe}^{2+}+5 / 2 \mathrm{H}_{2} \mathrm{O}+1 / 2 \mathrm{CO}_{2} .
$$

Studies made with steel industry by-product in Japan showed that their application increased iron oxide in paddy soil. The iron oxide acted as an oxidant (electron acceptor) and significantly inhibited the methane flux from paddy soils. The reduction in methane emission was attributed to both reduction in methane production and increased oxidation of methane produced. ${ }^{[41]}$

However, some of the steel industry by-products, such as iron slag, contain large amounts of calcium. Because of high content of calcium, they are basic in nature and retard reduction of $\mathrm{Fe}(\mathrm{III})$ to $\mathrm{Fe}(\mathrm{II})$ when added to wetland rice soils. Such products may not be very effective in controlling methane production or emissions from wetland rice fields.

To get a better understanding of the controls of methane production, microcosms planted with rice were used to study methane emission, porewater chemistry, and the potential role of ferric iron as a competitive electron acceptor. Methane formation in microcosms peaked after 60 days when porewater methane concentrations in the unrooted soil also reached their highest values. A rooted soil layer with low methane concentrations and high Eh developed on top of the lower unrooted soil. Methanogenesis in the rooted upper soil layer started at a very low rate, but increased dramatically (10-fold increase) after 25-40 days when ferric iron reduction had stopped (see data in Table 1 for the description of different phases in wetland soils). However, there was no difference or change in the numbers of culturable methanogens between the two layers, either at the start or at the end of the experiment. Therefore, the lag phase 
in methane production by the upper soil layer may have been caused either by competition for substrates or by direct inhibition, but not by population growth of methanogens. Oxygen release from rice roots controls methanogenesis in the rooted soil layer either directly or by the oxidation of ferrous iron. The results presented suggested that the presence of ferric iron, resulting from the input of oxygen via the roots resulted in a shift of electron flow from methanogenesis to ferric iron reduction. This interaction is assumed to be of major importance for the biogeochemistry of methane in wetland rice fields. ${ }^{[42]}$ These results are in agreement with the observations made by Roden and Wetzel, ${ }^{[43]}$ who showed that plant-mediated iron oxidation, from ferrous to ferric iron, reduced methane production in freshwater wetland sediments.

The research evidence presented by Frenzel et al. ${ }^{[42]}$ and Roden and Wetze ${ }^{[43]}$ clearly demonstrate the importance of ferric iron as an electron acceptor for reducing methane production in wetland rice soils and wetland sediments.

Similarly, the presence of nitrate, an electron acceptor, retards methane production in a way any other electron acceptor such as ferric iron does. Electron acceptors such as nitrate, sulfate, or ferric iron result in nitrate reducers, sulfate reducers, or ferric iron reducers in submerged rice soils utilize acetate and $\mathrm{H}_{2}$ more efficiently than methanogens. And, hence the reduction in methane production and emission. ${ }^{[13]}$

More importantly, electron acceptors such as ferric iron can also be regenerated by increasing the redox potential through the entry of air from the atmosphere. As discussed in the Introduction, iron redox play a dominant role, especially in the tropical rice paddy soils, which are rich in native iron. The regeneration of electron accepting ferric iron can also be achieved by soil and water management practices. Hence, in the use of ferric iron as terminal electron acceptor, we have the option. Ferric oxide and hydroxides as terminal electron acceptors can be either added from externally available sources such as steel industry by-products and naturally occurring pyrites $\left(\mathrm{FeS}_{2}\right)$ or they can be regenerated in-situ in the soil by manipulating Eh, for controlling methane emission from tropical rice paddies.

\section{PERSPECTIVES}

The easily reducible iron and organic matter are the two most important factors in controlling the redox reactions and soil reduction in submerged rice soils. Keeping the paddy rice soil reduced in the healthy 
redox potential zone will not only reduce production of methane, but would also be favorable to wetland rice production. ${ }^{[44,45]}$

The use of cheap sources of iron such as steel industry wastes and naturally occurring ores such as iron pyrites should be evaluated for mitigating the emission of methane from wetland rice fields. However, there is a need for developing chemical indices or criteria for characterizing active or free iron content of various substances which can be used for assessing iron products' capacity to supply electron accepting ferric iron for use in submerged rice paddies.

Also, there is need to study the fluxes of methane from wetland soils that are rich in reducible iron and cause iron toxicity to wetland rice. Such soils occupy large area in much of tropical Asia and Africa. ${ }^{[46,47]}$ It would be interesting to investigate the role of in-situ availability of terminal electron acceptors (ferric oxides and hydroxides) in soils that are rich in reducible iron and even cause iron-toxic to wetland rice. This area of research remains unexplored and needs research attention.

Simultaneously research should be conducted for developing strategies that reduce methane emission without compromising with the rice yields by using soil and water management practices that are conducive to regenerating ferric iron as an electron-accepting agent. It is hoped that this article will stimulate research along the lines discussed for controlling methane emission to the atmosphere from rice fields without compromising with rice production in wetlands, which have had contributed handsomely to global rice supply. ${ }^{[48]}$

\section{REFERENCES}

1. Mosier, A.R. Soil processes and global warming. Biol. Fertil. Soils 1998, 27, 221-229.

2. Neue, H.U. Methane emission from rice fields. BioScience 1993, 43, 466-474.

3. Aulakh, M.S.; Wassmann, R.; Rennenberg, H. Methane emission from rice fields: quantification, mechanisms, role of management, and mitigation options. Adv. Agron. 2001, 70, 193-260.

4. Wang, Z.P.; DeLaune, R.D.; Masscheleyn, P.H.; Patrick, W.H., Jr. Soil redox and $\mathrm{pH}$ effects on methane production in a flooded rice soil. Soil Sci. Soc. Am. J. 1993, 57, 382-385.

5. Vogels, G.D.; Kjeltjens, J.T.; Van der Drift, C. Biochemistry of methane production. In Biology of Anaerobic Microorganisms; Zehnder, A.S.B., Ed.; John Wiley: New York, 1988; 707-770. 
6. Takai, Y. The mechanism of methane formation in flooded soils. Soil Sci. Plant Nutr. 1970, 16, 238-244.

7. Takai, Y.; Koyama, T.; Kamura, T. Microbial metabolism in reduction process of paddy soil, Part 1. Soil Plant Food 1956, 2, 63-66.

8. Conrad, R. Control of microbial methane production in wetland rice fields. Nutrient Cycl. Agroecosyst. 2002, 64, 59-69.

9. Ponnamperuma, F.N. The chemistry of submerged soils. Adv. Agron. 1972, 24, 29-96.

10. Patrick, W.H., Jr.; Reddy, C.N. Chemical changes in rice soil. Soil and Rice; International Rice Research Institute: Manila, Philippines, 1978; 361-379.

11. Acharya, C.N. Studies on the anaerobic decomposition of plant materials. I. the anaerobic decomposition of rice straw (Oryza sativa). Biochem. J. 1935, 29, 528-542.

12. Watanabe, I. Anaerobic decomposition of organic matter. Organic Matter and Rice; International Rice Research Institute: Manila, Phillipines, 1984; 237-258.

13. Achtnich, C.; Bak, F.; Conrad, R. Competition for electron donors among nitrate reducers, ferric iron reducers, sulfate reducers and methanogens in anoxic paddy soil. Biol. Fertil. Soils 1995, 19, 65-72.

14. Martens, C.S.; Berner, R.A. Methane production in terrestrial waters of sulfate-depleted marine sediments. Science 1974, 185, $1167-1168$.

15. Patel, G.B.; Roth, L.A. Effect of sodium chloride on growth and methane production of methanogens. Canadian J. Microbiol. 1977, 23, 893-897.

16. Koyama, T.; Hishida, M.; Tomino, T. Influence of sea salt on the soil metabolism II: on the gaseous metabolism. Soil Sci. Plant Nutr. 1970, 16, 81-86.

17. Denier van der Gon, H.A.C.; Neue, H.U. Methane emission from a wetland rice field as affected by salinity. Plant Soil 1995, 170, 307-313.

18. Parashar, D.C.; Rai, J.; Gupta, P.K.; Singh, N. Parameters affecting methane emission from paddy fields. Indian J. Radio Space Phys. 1991, 20, 12-17.

19. Delwiche, C.C.; Cicerone, R.J. Factors affecting methane production under rice. Global Biogeochem. Cycles 1993, 7, 143-155.

20. Lindau, C.W.; Alford, D.P.; Bollich, P.K.; Linscombe, S.D. Inhibition of methane evolution by calcium sulfate addition to flooded rice. Plant Soil 1994, 158, 299-301. 
21. Adhya, T.K.; Pattnaik, P.; Satpathy, S.N.; Kumaraswamy, S.; Sethunathan, N. Influence of phosphorus application on methane emission and production in flooded paddy soils. Soil Biol. Biochem. 1997, 30, 177-181.

22. Kesheng, S.; Zhen, L. Effect of rice cultivars and fertilizer management on methane emission in a rice paddy in Beijing. Nutrient Cycl. Agroecosyst. 1997, 49, 139-146.

23. Shoenheit, P.; Kristjansson, J.K.; Thauer, R.K. Kinetic mechanism for the ability of sulfate reducers to outcompete methanogens for acetate. Arch. Microbiol. 1982, 132, 285-288.

24. Hori, K.; Inubushi, K.; Matsumoto, S.; Wada, H. Competition for hydrogen between methane formation and sulfate reduction in a paddy soil. Jpn. J. Soil Sci. Plant Nutr. 1993, 64, 363-367.

25. Ratering, S.; Conrad, R. Effects of short-term drainage and aeration on the production of methane in submerged rice soil. Global Change Biol. 1998, 4, 397-407.

26. Lovley, D.R.; Goodwin, S. Hydrogen concentrations as an indicator of the predominant terminal electron-accepting reactions in aquatic sediments. Geochim. Cosmochim. 1998, 52, 2993-3003.

27. Sahrawat, K.L.; Narteh, L.T. Organic matter and reducible iron control of ammonium production in submerged soils. Commun. Soil Sci. Plant Anal. 2001, 32, 1543-1550.

28. Lovley, D.R. Microbial reduction of iron, manganese, and other metals. Adv. Agron. 1995, 54, 175-231.

29. Sahrawat, K.L. Reducible iron affects organic matter oxidation and ammonium production in wetland soils and sediments. Current Sci. 2002, 83, 1434-1435.

30. Yao, H.; Conrad, R.; Wassmann, R.; Neue, H.U. Effect of soil characteristics on sequential reduction and methane production in sixteen paddy soils from China, the Philippines, and Italy. Biogeochemistry 1999, 47, 269-295.

31. Krueger, M.; Conrad, R. Microbial process influencing methane emission from rice fields. Global Change Biol. 2001, 7, 49-63.

32. Takai, Y. Reduction and microbial metabolism in paddy soils (3) [in Japanese]. Nogyo Gijitsu Agric. Technol. 1961, 19, 122-126.

33. Asami, T.; Takai, Y. Relation between reduction of free iron oxide and formation of gases in paddy soil [in Japanese]. J. Sci. Soil Manure, Jpn. 1970, 41, 48-55.

34. Koyama, T.; Kimura, M. Inhibitors of methane production in paddy soils. Soil Sci. Plant Nutr. 1998, 44, 667-674. 
35. Yuan, W.L.; Ponnamperuma, F.N. Chemical retardation of the reduction of flooded soils and the growth of rice. Plant Soil 1966, 25, 347-360.

36. Patrick, W.H., Jr.; Gotoh, S.; Williams, B.G. Strengite dissolution in flooded soils and sediments. Science 1973, 179, 564-565.

37. Munch, J.C.; Ottow, J.C.W. Preferential reduction of amorphous to crystalline iron oxides by bacterial activity. Soil Sci. 1980, 129, 15-21.

38. Wahid, P.A.; Kamalam, N.V. Reductive dissolution of crystalline and amorphous $\mathrm{Fe}(\mathrm{III})$ oxides by microorganisms in submerged soil. Biol Fertil. Soils 1993, 15, 144-148.

39. Olaleye, A.O.; Ogunkunle, A.O.; Sahrawat, K.L. Forms and pedogenic distribution of extractable iron in selected wetland soils in Nigeria. Commun. Soil Sci. Plant Anal. 2000, 31, 923-941.

40. Schwertmann, U. Inhibitory effect of soil organic matter on the crystallization of amorphous ferric hydroxide. Nature 1966, 212, 645-646.

41. Furukawa, Y.; Inubushi, K. Feasible suppression technique of methane emission from paddy soil by iron amendment. Nutrient Cycl. Agroecosyst. 2002, 64, 193-201.

42. Frenzel, P.; Bosse, U.; Janssen, P.H. Rice roots and methanogenesis in a paddy soil: ferric iron as an alternative electron acceptor in the rooted soil. Soil Biol. Biochem. 1999, 31, 421-430.

43. Roden, E.E.; Wetzel, R.G. Organic carbon oxidation and suppression of methane production by microbial Fe(III) oxide reduction in vegetated and unvegetated freshwater wetland sediments. Limnol. Oceanogr. 1996, 41, 1733-1748.

44. Narteh, L.T.; Sahrawat, K.L. Influence of flooding on electrochemical and chemical properties of West African soils. Geoderma 1999, 87, 179-207.

45. Sahrawat, K.L. Flooding soil: a great equalizer of diversity in soil chemical fertility. Oryza 1998, 35, 300-305.

46. Sahrawat, K.L.; Mulbah, C.K.; Diatta, S.; DeLaune, R.D.; Patrick, W.H., Jr.; Singh, B.N.; Jones, M.P. The role of tolerant genotypes and plant nutrients in the management of iron toxicity in lowland rice. J. Agric. Sci., Cambridge 1996, 126, 143-149.

47. Moormann, F.R.; van Breemen, N. Rice: Soil, Water, Land; International Rice Research Institute: Manila, Philippines, 1978.

48. Cassman, K.G.; Pingali, P.L. Intensification of irrigated rice system: learning from the past to meet future challenges. Geojournal 1995, 35, 299-305. 
Copyright of Communications in Soil Science \& Plant Analysis is the property of Marcel Dekker Inc. and its content may not be copied or emailed to multiple sites or posted to a listserv without the copyright holder's express written permission. However, users may print, download, or email articles for individual use. 